\title{
PENGARUH CURRENT RATIO, PERPUTARAN PERSEDIAAN, DEBT TO ASSET RATIO, GROWTH DAN SIZE TERHADAP PROFITABILITAS PERUSAHAAN RETAIL SEKTOR TRADE, INVESTMENT DAN SERVICE YANG TERDAFTAR DI BURSA EFEK INDONESIA
}

\section{THE EFFECT OF CURRENT RATIO, INVENTORY TURNOVER, DEBT TO RATIO, GROWTH, SIZE OF MANUFACTURING COMPANIES SECTOR TRADE, INVESMENT AND SERVICE}

\author{
Annisa Nauli ${ }^{1}$, Citra William ${ }^{2}$, Tiffanny Meiluartha ${ }^{3}$, Alviana Celia Jansen ${ }^{4}$ \\ Universitas Prima Indonesia ${ }^{1,2,3,4}$ \\ williamcitra88@gmail.com²
}

\begin{abstract}
The development of companies nowadays have been growing rapidly and causing intense competition in the market. Trade, service, and investment sector companies are emerging in Indonesia. Thus, this study aims to identify the impact of current ratio, inventory turnover, debt to asset ratio, growth and size towards firm's profitability in Trade, Service, and Investment Companies Listed in Indonesia Stock Exchange (IDX) from year 2016-2019. The research type of this study is quantitative method. The data is classified as quantitative and ratio scale. This study uses secondary data. The population for this study is 154 trade, service, and investment sector companies listed in Indonesia Stock Exchange (IDX) from year 2016-2019. The sample for this study is 65 trade, service, and investment sector companies listed in Indonesia Stock Exchange (IDX) from year 2016-2019 using observational sampling method. The model of this study is multiple linear regression. The result of this study shows that current ratio, inventory turnover, debt to asset ratio, growth and size partially and simulteneously do not affect firm's profitability in Trade, Service, and Investment Companies Listed in Indonesia Stock Exchange (IDX) from year 2016-2019.
\end{abstract}

Keywords : Current Ratio, Inventory Turnover, Debt To Asset Ratio, Growth, Size dan Profitability

\footnotetext{
ABSTRAK

Perkembangan perusahaan saat ini semakin pesat dan mengakibatkan persaingan yang terjadi semakin tajam. Adapun perusahaan retail sektor trade, investment dan service yang banyak bermunculan di negara Indonesia. Tujuan penelitian ini adalah Current Ratio, Perputaran Persediaan, Debt To Asset Ratio, Growth Dan Sizeberpengaruh Terhadap Profitabilitas Perusahaan Retail Sektor Trade, Investment Dan Service Yang Terdaftar Di Bursa Efek Indonesia Tahun 20162019. Penelitian ini memakai penelitian kuantitatif. Data penelitian tergolong kuantitatif dan skala rasio. Jenis data yang dipakai adalah sekunder. Populasi penelitian ini adalah 154 perusahaan retail sektor trade, investment dan service yang terdaftar di Bursa Efek Indonesia Tahun 2016-2019.. Sampel penelitian sebanyak 39 Perusahaan retail sektor trade, investment dan service yang terdaftar di Bursa Efek Indonesia Tahun 2016-2019 dengan sampel pengamatan sebanyak 156 observasi pengamatan. Model penelitian ini adalah regresi linear berganda dan model penelitian adalah regresi linear berganda.
} 
Hasil akhir penelitian ini adalah Current Ratio, Perputaran Persediaan, Debt To Asset Ratio, Growth Dan Size secara parsial dan simultan tidak berpengaruh Terhadap Profitabilitas Perusahaan Retail Sektor Trade, Investment Dan Service Yang Terdaftar Di Bursa Efek Indonesia Tahun 2016-2019.

Kata Kunci : Current Ratio,Perputaran Persediaan,Debt To Asset Ratio,Growth,SizedanProfitabilitas.

\section{PENDAHULUAN}

Perkembangan perusahaan saat ini semakin pesat dan mengakibatkan persaingan yang terjadi semakin tajam. Adapun perusahaan retail sektor trade, investment dan service yang banyak bermunculan di negara Indonesia. Namun perusahaan ini juga menghadapi masalah laba. Hal ini terjadi penurunan laba diakibatkan harga barang retail mengalami kenaikan. Munculnya fenomena belanja online di masyarakat serta ketatnya persaingan membuat pertumbuhan penjualan emiten ritel mengalami tren penurunan dalam lima tahun terakhir. Ditambah lagi dengan turunnya daya beli konsumen membuat beberapa perusahaan ritel mencatat penurunan penjualan pada 2017.

Berdasarkan laporan keuangan emiten yang telah dipublikasikan dan diolah Katadata menunjukkan 10 emiten sektor ritel pada 2017 pertumbuhan penjualan/pendapatan mengalami perlambatan dibanding pada 2013. Penurunan pertumbuhan penjualan terdalam dicatat PT Electronic City Indonesia Tbk (ECII). Sementara PT Ace Hardware Indonesia Tbk (ACES) mengalami penurunan pertumbuhan penjualan terendahpada 2013. Bahkan tiga emiten ritel seperti PT Ramayana Lestari Tbk (RALS), PT Hero Supermarket Tbk dan PT Matahari Putra Prima Tbk (LPPF) penjualannya mengalami penurunan penjualan pada tahun 2017

Perusahaan dalam mengelola usahanya tidak terlepas dari laba dan alat ukur laba yang sering digunakan ini profitabilitas (Luckyta, 2020). Apabila perusahaan tidak memiliki laba maka perusahaan tersebut tidak mampu mempertahankan kelangsungan hidupnya. Profitabilitas bagi perusahaan berperan penting untuk mempertahankan kelangsungan hidupnya. Adapun beberapa faktor yang mempengaruhi profitabilitas adalah current ratio, Perputaran Persediaan, Debt To Asset Ratio, Growth dan Size.

Laba yang dimiliki perusahaan sebagian dijadikan untuk membayar kewajiban lancar. Salah satu alat ukut yang digunakan perusahaan dalam membayar kewajiban lancar berupa Current Ratio. Apabila hutang jangka pendek tidak diutamakan pihak manajemen untuk melunasi maka berakibat pada kemacetan kegiatan operasional perusahaan seperti pembelian bahan baku perusahaan dengan menggunakan hutang usaha tidak dibayarkan sesuai perjanjian dengan supplier maka supplier tidak akan menyuplai bahan baku kepada perusahaan.

Semakin besar perbandingan aktiva lancar dan kewajiban lancar semakin tinggi kemampuan perusahaan menutupi kewajiban jangka pendeknya. Aktiva lancar adalah uang kas ataupun aktiva lainnya dapat diharapkan untuk dicairkan atau ditukarkan dengan uang tunai, dijual dalam periode berikutnya (satu tahun). Aktiva lancar tinggi akan mempengaruhi laba dimana perusahaan harus menyediakan persediaan yang cukup tinggi maka 
dapat menghasilkan penjualan tinggi dan meningkatkan laba perusahaan (Alpi, 2018).

Laba perusahaan berkaitan dengan persediaan yang tersedia di gudang. Masalah yang sering dihadapi perusahaan terutama sulit untuk memprediksi dengan tepat kebutuhan akan bahan baku dan barang jadi, bagaimana perusahaan dapat menyediakan persediaan tepat waktu dan sesuai kebutuhan. Masalah penentuan jumlah dana dalam persediaan mempunyai dampak langsung terhadap keuntungan perusahaan. Tinggi rendahnya perputaran persediaan mempunyai pengaruh langsung terhadap besar kecilnya modal kerja perusahaan untuk mendapatkan laba yang besar.Semakin cepat perputaran persediaan,maka semakin kecil jumlah modal kerja yang diinvestasikan dalam persediaan sehingga semakin tinggi tingkat profitabilitas tertentu yang diperoleh dari penjualan persediaan sehingga semakin tinggi tingkat profitabilitas yang diperoleh dari penjualan persediaan tersebut.

Profitabilitas akan mengalami peningkatan karena persediaan yang terdapat dalam perusahaan dapat dijual pada jangka waktu dan jumlah yang diharapkan. Sebaliknya, semakin lambat perputaran persediaan,maka makin besar jumlah modal kerja yang diinvestasikan dalam persediaan dan semakin besar pula risiko kerugiaan yang mungkin dialami perusahaan sehingga semakin rendah tingkat profitabilitas yang diperoleh dari penjualan persediaan tersebut (Lestiowati, 2018)

Tinggi rendahnya laba yang diperoleh perusahaan secara tidak langsung berkaitan dengan tingkat utang yang terjadi di perusahaan. Biasanya perusahaan menggunakan
Debt To Asset Ratio untuk mengukur pembiayaaan perusahaan dengan utang (Tannia, 2020). Pada dasarnya, jika perusahaan meningkatkan jumlah utang sebagai sumber dananya hal tersebut dapat meningkatkan risiko keuangan. Jika perusahaan tidak dapat mengelola dana yang diperoleh dari utang secara produktif, hal tersebut dapat memberikan pengaruh negatif dan berdampak terhadap menurunnya profitabilitas perusahaan. Sebaliknya jika utang tersebut dapat dikelola dengan baik dan digunakan untuk proyek investasi yang produktif, hal tersebut dapat memberikan pengaruh yang positif dan berdampak terhadap peningkatan profitabilitas perusahaan. Utang yang besar akan berdampak pada resiko keuangan yang harus ditanggung perusahaan atau terbebani dengan pembayaran bunga dalam jumlah yang besar.Namun apabila dana hasil pinjaman tersebut digunakan secara efisien dan efektif maka hal ini akan memberikan peluang yang besar bagi perusahaan dalam meningkatkan keuntungan (Alpi, 2018).

Laba ini dipengaruhi oleh tingkat pertumbuhan penjualan yang terjadi di perusahaan. Biasanya alat ukur yang digunakan perusahaan untuk mengetahui tinggi rendahnya penjualan berupa growth. Jika growth yang tinggi dapat meningkatkan profitabilitas sedangkan growth yang rendah dapat menurunkan profitabilitas perusahaan. Akhir-akhir ini growth perusahaan mengalami penurunan dan kurang stabil sehingga tingkat profitabilitas perusahaan mengalami penurunan. Perusahaan yang meningkatkan pertumbuhan penjualan dengan menggunakan asset secara efisiendan mengarah pada penggunaan sumber daya yang optimal menunjukkan perusahaan tersebut dapat mempertahankan posisi ekonomi dan 
kelangsungan hidupnya memberikan dampak positif terhadap ROA. Ketika jumlahbarangyang dijual semakin besar, maka biaya rata-rata persatuan produk akan semakin kecil sehingga ROA yang dihasilkan suatu perusahaan akan meningkat (Miswanto et al., 2017). Size perusahaan yang besar dapat meningkatkan profitabilitas sedangkan size perusahaan yang kecil menunjukkan penurunan profitabilitas. Perusahaan yang berukuran besar memiliki tingkat penjualan yang tinggi sehingga profitabilitas yang terjadi di perusahaan tinggi dibandingkan perusahaan yang berukuran kecil selalu menunjukkan tingkat penjualan yang terjadi di perusahaan rendah. Suatu perusahaan yang mempunyai ukuran yang cukup besar tentu dapat dikatakan memperoleh profit yang tinggi karena mampu mengolah sumber daya yang ada di perusahaan tersebut (Wikardi \& Wiyani, 2017).

Aktiva lancar yang terjadi di PT Ace Hardware Indonesia, Tbk di tahun 2018 sebesar Rp 4.096.280 mengalami peningkatan yang seharusnya dapat menurunkan laba bersih setelah pajak namun kenyataan aktiva lancar dapat mendorong peningkatan laba bersih di tahun 2018 sebesar Rp 976.273.

PT Astra Graphia memiliki persediaan di tahun 2018 sebesar 380.492 menurun seharusnya dapat menurunkan laba bersih namin kenyataan dapat meningkatkan laba bersih di tahun 2018 sebesar Rp 270.404. Total aktiva di tahun 2018 sebesar Rp 2.271.344 menurun seharusnya menurunkan laba bersih tetapi kenyataannya justru meningkatkan laba bersih sebesar Rp 270.404.

PT Ramayana Lestari Sentosa,Tbk memiliki total hutang di tahun 2018 sebesar Rp 1.415.582 meningkat seharusnya dapat menurunkan laba bersih namun kenyataan di tahun 2018 total hutang meningkat sebesar Rp 587.105.

Berdasarkan dari latar belakang di atas mendorong peneliti untuk membahas judul penelitian "Pengaruh Current Ratio, Perputaran Persediaan, Debt To Asset Ratio, Growth Dan Size Terhadap Profitabilitas Perusahaan Retail Sektor Trade, Investment Dan Service Yang Terdaftar Di Bursa Efek Indonesia Tahun 2016-2019”.

\section{METODE PENELITIAN}

Pendekatan penelitian kuantitatif. Jenis data yang digunakan peneliti dalam penelitian ini adalah data kuantitatif. Sumber data penelitian adalah sumber data sekunder.

\section{Populasi dan Sampel}

Populasi dari penelitian ini yaitu seluruh perusahaan manufaktur yang listing atau terdaftar pada Bursa Efek Indonesia (BEI) dari tahun 2016 sampai dengan 2019. Populasi pada penelitian ini berjumlah 154 perusahaan. Pengambilan sampel pada penelitian ini didasarkan pada beberapa pertimbangan dan kriteria tertentu yang sudah ditetapkan sebelumnya.Adapun kriteria dalam pengambilan sampel ini adalah sebagai berikut :

Tabel 1 Sampel Penelitian

\begin{tabular}{clc}
\hline No. Kriteria & $\begin{array}{l}\text { Jumlah } \\
\text { Sampel }\end{array}$ \\
\hline \multicolumn{4}{c}{$\begin{array}{l}\text { Perusahaan retail sektor trade, } \\
\text { investment dan service yang } \\
\text { terdaftar di Bursa Efek } \\
\text { Indonesia Tahun 2016-2019 }\end{array}$} \\
\hline 2 & $\begin{array}{l}\text { Perusahaan retail sektor trade, } \\
\text { investment dan service yang } \\
\text { tidak mempublikasi laporan } \\
\text { keuangan Tahun 2016-2019 }\end{array}$ \\
\hline 3 & $\begin{array}{l}\text { Perusahaan retail sektor trade, } \\
\text { investment dan service yang } \\
\text { tidak memperoleh laba dan } \\
\text { kelengkapan variabel penelitian }\end{array}$ \\
\hline
\end{tabular}




\begin{tabular}{cc}
\hline $\begin{array}{c}\text { secara berturut-turut } \\
\text { periode Tahun 2016-2019 }\end{array}$ & dari \\
\hline Jumlah Sampel Perusahaan & $\mathbf{3 9}$ \\
\hline Total Sampel (4 x 39) & 156 \\
\hline
\end{tabular}

Sumber : www.idx.co.id (data diolah)

Sampel penelitian sebanyak 39 Perusahaan retail sektor trade, investment dan service yang terdaftar di Bursa Efek Indonesia Tahun 2016-2019 dengan sampel pengamatan sebanyak 156 observasi pengamatan.

\section{Teknik Analisis Data}

Teknik analisis yang digunakan dalam penelitian ini yaitu uji regresi linear berganda. Setelah dilakukan uji asumsi klasik maka dilakukan uji regresi linear berganda. Analisis regresi linear berganda bertujuan untuk menguji hubungan antara beberapa variabel independen dan variabel dependen. Adapun variabel independen dalam penelitian ini yaitu Current Ratio $\left(\mathrm{X}_{1}\right)$, Perputaran Persediaan $\left(\mathrm{X}_{2}\right)$ dan Debt To Asset Ratio $\left(\mathrm{X}_{3}\right)$, Growth $\left(\mathrm{X}_{4}\right)$ dan Size $\left(\mathrm{X}_{5}\right)$ sedangkan variabel dependen dalam penelitian ini yaitu Profitabilitas (Y). Mode persamaan regresi dalam penelitian ini yaitu sebagai berikut :

$$
\mathbf{Y}=\mathbf{a}+\mathbf{b}_{1} \mathbf{X}_{1}+\mathbf{b}_{2} \mathbf{X}_{2}+\mathbf{b}_{3} \mathbf{X}_{3}+\mathbf{b}_{4} \mathbf{X}_{4}+\mathbf{b}_{5} \mathbf{X}_{5}+e
$$

\section{Keterangan :}

$\begin{array}{ll}\mathrm{Y} & \text { : Profitabilitas } \\ \mathrm{a} & \text { : konstanta } \\ \mathrm{X}_{1} & \text { : Current Ratio } \\ \mathrm{X}_{2} & \text { :Perputaran Persediaan } \\ \mathrm{X}_{3} & \text { :Debt To Asset Ratio } \\ \mathrm{X}_{4} & \text { :Growth } \\ \mathrm{X}_{5} & \text { :Size } \\ \mathrm{b}_{1,2,3,4} & \text { : besaran koefisien regresi dari masing- } \\ \text { masing } & \text { variabel } \\ \mathrm{e} & \text { : error }\end{array}$

\section{Uji Normalitas}

Uji normalitas yaitu pengujian yang bertujuan untuk melihat apakah variabel independen maupun dependen berdistribusi secara normal atau tidak.
Untuk menguji normalitas dalam penelitian ini digunakan metode One Sample Solgomorov Sminov Test. Dasar pengambilan keputusan adalah jika 2tailed $>0,05$, maka model regresi memenuhi asumsi normalitas begitu juga sebaliknya.

\section{Uji Multikolinearitas}

Tujuan dari uji multikolinearitas dilakukan adalah untuk menguji model regresi, apakah pada variabel independen terdapat korelasi antara variabel satu dengan lainnya. Hasil yang baik adalah antar variabel bebasnya tidak terjadi korelasi. Model regresi yang baik yaitu model yang memiliki nilai tolerance $>0,10$ dan nilai VIF $<10$.

\section{Uji Autokolerasi}

Uji Autokorelasi bertujuan untuk mengetahui apakah dalam model regresi ada regresi antar kesalahan pengganggu pada periode ( $t$ ) dengan periode $t-1$ (sebelumnya). Jika terjadi korelasi maka terdapat masalah korelasi. Masalah ini timbul karena residual (kesalahan pengganggu) tidak bebas dari satu observasi ke observasi lainnya. Cara yang dapat digunakan untuk mendeteksi ada atau tidaknya autokorelasi adalah dengan uji Durbin Watson (DW). Untuk pengambilan keputusan ada atau tidaknya autokorelasi dalam suatu model dapat digunakan patokan nilai dari $\mathrm{dL}<(4-\mathrm{DW})>\mathrm{dU}$.

\section{Koefisien Determinasi $\left(\mathbf{R}^{\mathbf{2}}\right)$}

Untuk menguji kelayakan model maka digunakan Uji Koefisien Determinasi $\left(\mathrm{R}^{2}\right)$, koefisien determinasi $\left(\mathrm{R}^{2}\right)$ pada intinya mengukur seberapa jauh kemampuan modal dalam menerangkan variasi variabel terikat. Nilai $\left(\mathrm{R}^{2}\right)$ yang kecil diartikan sebagai kemampuan variabel independen dalam 
menerangkan variasi variabel dependen sangat terbatas.

\section{Pengujian Hipotesis Simultan (Uji F)}

Uji Statistik F pada dasarnya bertujuan untuk melihat apakah semua variabel independen atau bebas yang dimasukkan kedalam model mempunya pengaruh terhadap variabel dependen atau terikat. Prosedur yang dapat digunakan adalah :

1. Dalam penelitian ini digunakan taraf signifikan sebesar $5 \%$ atau 0,05 dengan derajat bebas (n-k), dimana $n$ adalah jumlah data observasi dan $\mathrm{k}$ adalah jumlah variabel.

2. Kriteria keputusan adalah uji kecocokan model dengan syarat model ditolak jika $\alpha>0,05$ dan model diterima jika $\alpha<0,05$.

\section{Pengujian Hipotesis Parsial (Uji T)}

Uji $\mathrm{T}$ pada dasarnya digunakan untuk menampilkan tingkat pengaruh suatu variabel independen atau penjelas secara individual (parsial) dalam menerangkan variasi dari variabel dependen. Dalam pengujian ini digunakan tingkat signifikasi sebesar 0,05 atau $\alpha=5 \%$.

HASIL DAN PEMBAHASAN Analisis Regresi Berganda

Tabel 2 Hasil Analisis Regresi Linear Berganda

\begin{tabular}{llrr}
\hline & \multicolumn{2}{c}{$\begin{array}{c}\text { Unstandardized } \\
\text { Coefficients }\end{array}$} \\
\cline { 2 - 4 } Model & \multicolumn{1}{c}{ B } & Std. Error \\
\hline 1 & (Constant) & -4.415 & 5.074 \\
\cline { 2 - 4 } & Ln_CR & .343 & .184 \\
\cline { 2 - 4 } Ln_INVT & .140 & .072 \\
\cline { 2 - 3 } Ln_DAR & .002 & .219 \\
\hline Ln_GROWTH & .023 & .085 \\
\hline Ln_SIZE & .322 & 1.501 \\
\hline
\end{tabular}

Sumber : Data Olahan SPSS (2020)

Berdasarkan tabel 1 diatas, maka dapat diperoleh model persamaan regresi linear berganda sebagai berikut :

$$
\begin{array}{r}
\text { Ln_ROA }=-4,415+0,343 \text { Ln_CR }+ \\
0,140 \quad \text { Ln_INVT }+0,002 \\
\text { Ln_DAR }+\quad 0,023 \\
\text { Ln_Growth }+0,322 \text { Ln_Size }
\end{array}
$$

Hasil interpretasi dari regresi tersebut adalah sebagai berikut:

1. Nilai a sebesar $-4,415$ artinya jika variabelCurrent Ratio, Perputaran Persediaan, Debt To Asset Ratio, Growth Dan Sizedianggap konstan, maka profitabilitasadalah sebesar $-4,415$.

2. Nilai koefisien Current Ratio adalah 0,343. Ini menunjukkan bahwa setiap peningkatan Current Ratiosatu kali maka profitabilitas akan mengalami kenaikan sebesar 0,343 .

3. Nilai koefisien Perputaran Persediaan sebesar 0,140. Ini menunjukkan bahwa setiap peningkatan Perputaran Persediaan satu kali maka profitabilitas akan mengalami kenaikan sebesar 0,140.

4. Nilai koefisien Debt To Asset Ratio sebesar 0,002. Ini menunjukkan bahwa setiap peningkatan Debt To Asset Ratio satu kali maka profitabilitas akan mengalami kenaikan sebesar 0,002 .

5. Nilai koefisien Growth sebesar 0,023 . Ini menunjukkan bahwa setiap peningkatan Growthsatu kali maka profitabilitas akan mengalami kenaikan sebesar 0,023.

6. Nilai koefisien Size sebesar 0,322. Ini menunjukkan bahwa setiap peningkatan Sizesatu kali maka profitabilitas akan mengalami kenaikan sebesar 0,322 . 


\section{Koefisien Determinasi $\left(\mathbf{R}^{2}\right)$}

Tabel 3 Koefisien Determinasi

\begin{tabular}{llrrr}
\hline Model & $\mathrm{R}$ & R Square & $\begin{array}{c}\text { Adjusted R } \\
\text { Square }\end{array}$ & $\begin{array}{r}\text { Std. Error of } \\
\text { the Estimate }\end{array}$ \\
\hline 1 & $.300^{\mathrm{a}}$ & .090 & .051 & .87257 \\
\hline
\end{tabular}

a. Predictors: (Constant), Ln SIZE, Ln GROWTH,

Ln_DAR, Ln_INVT, Ln_CR

b. Dependent Variable: Ln_ROA

Sumber : Data Olahan SPSS (2020)

Dari tabel diatas diketahui bahwa nilai adjusted $R$ Square $\left(\mathrm{R}^{2}\right)$ sebesar 0,051 atau sama dengan $5,1 \%$. variabel independen berpengaruh terhadap kebijakan dividen sebesar $5,1 \%$ dan sisanya $94,9 \%$ dipengaruhi variabel lain.

\section{Pengujian Hipotesis Simultan (Uji F)}

Tabel 4 Hasil Uji F

\begin{tabular}{llrrrrr}
\hline \multirow{2}{*}{ Model } & $\begin{array}{c}\text { Sum of } \\
\text { Squares }\end{array}$ & \multicolumn{1}{c}{ df } & $\begin{array}{c}\text { Mean } \\
\text { Square }\end{array}$ & F & Sig. \\
\hline \multirow{2}{*}{1} & Regression & 8.714 & 5 & 1.743 & 2.289 & $.050^{\mathrm{b}}$ \\
\cline { 2 - 7 } & Residual & 88.319 & 116 & .761 & & \\
\cline { 2 - 6 } & Total & 97.033 & 121 & & & \\
\hline
\end{tabular}

a. Dependent Variable: Ln ROA

b. Predictors: (Constant), Ln_SIZE, Ln_GROWTH,

Ln_DAR, Ln_INVT, Ln_CR

Sumber : Data Olahan SPSS (2020)

Pada tabel 4 diatas diketahui hasil $F_{\text {hitung }}$ adalah sebesar 2,289 dengan nilai signifikan 0,050 sedangkan $F_{\text {tabel }}(122-6=116)$ adalah sebesar 2,29 maka kesimpulannya adalah $F_{\text {hitung }}$ $<\mathrm{F}_{\text {tabel }}$ yaitu $2,289<2,29$ sehingga keputusannya adalah Ho ditolak dan $\mathrm{Ha}$ diterima, artinya Current Ratio, Perputaran Persediaan, Debt To Asset Ratio, Growth Dan Sizetidak berpengaruh Terhadap Profitabilitas Perusahaan Retail Sektor Trade, Investment Dan Service Yang Terdaftar Di Bursa Efek Indonesia Tahun 2016-2019.

\section{Pengujian Hipotesis Parsial (Uji T) Tabel 5 Hasil Uji T}

\begin{tabular}{llrr} 
Model & & $\mathrm{t}$ & \multicolumn{1}{c}{ Sig. } \\
\hline 1 & (Constant) & -.870 & .386 \\
\cline { 2 - 4 } & Ln_CR & 1.867 & .064 \\
\cline { 2 - 4 } & Ln_INVT & 1.955 & .053 \\
\cline { 2 - 4 } & Ln_DAR & .009 & .993 \\
\cline { 2 - 4 } & Ln_GROWTH & .269 & .789 \\
\cline { 2 - 3 } & Ln_SIZE & .215 & .830 \\
\hline
\end{tabular}

Sumber : Data Olahan SPSS (2020)

Dari tabel hasil uji diatas dapat dijelaskan hasil pengujian hipotesis secara parsial sebagai berikut :

1. Current Ratio mempunyai nilai $t_{\text {hitung }}$ adalah sebesar 1,867 dengan nilai signifikan 0,064 sedangkan $t_{\text {tabel }}(122-5=117)$ adalah sebesar 1,980dan nilai signifikan 0,064 di atas signifikan 0,05 sehingga kesimpulannya adalah $\mathrm{t}_{\text {hitung }}<\mathrm{t}_{\text {tabel }}$ yaitu $\quad 1,867<1,980 \quad$ maka keputusannya adalah Ho diterima dan $\mathrm{H}_{\mathrm{a}}$ ditolak, artinya variabel Current Ratiotidak berpengaruh Terhadap Profitabilitas Perusahaan Retail Sektor Trade, Investment Dan Service Yang Terdaftar Di Bursa Efek Indonesia Tahun 2016-2019.

2. Variabel Perputaran Persediaan mempunyai nilai $t_{\text {hitung }} 1,955$ dengan nilai signifikan 0,053 sedangkan $t_{\text {tabel }}$ adalah sebesar 1,980dan nilai signifikan 0,053 berada di atas signifikan $\quad 0,05$ maka kesimpulannya adalah $\mathrm{t}_{\text {hitung }}<\mathrm{t}_{\text {tabel }}$ yaitu $1,955<1,980 \quad$ sehingga keputusannya adalah Ho diterima dan $\mathrm{H}_{\mathrm{a}}$ ditolak, artinya variabel Perputaran Persediaan tidak berpengaruh Terhadap Profitabilitas Perusahaan Retail Sektor Trade, Investment Dan Service Yang Terdaftar Di Bursa Efek Indonesia Tahun 2016-2019. 
3. Debt To Asset Ratio mempunyai nilai $t_{\text {hitung }}$ adalah sebesar 0,009 dengan nilai signifikan 0,993 sedangkan $t_{\text {tabel }}(122-5=117)$ adalah sebesar 1,980dan nilai signifikan 0,993 di atas signifikan 0,05 sehingga kesimpulannya adalah $\mathrm{t}_{\text {hitung }}<\mathrm{t}_{\text {tabel }}$ yaitu $0,009<1,980$ maka keputusannya adalah Ho diterima dan $\mathrm{H}_{\mathrm{a}}$ ditolak, artinya variabel Debt To Asset Ratiotidak berpengaruh Terhadap Profitabilitas Perusahaan Retail Sektor Trade, Investment Dan Service Yang Terdaftar Di Bursa Efek Indonesia Tahun 2016-2019.

4. Growth mempunyai nilai thitung adalah sebesar 0,269 dengan nilai signifikan $\quad 0,789 \quad$ sedangkan $t_{\text {tabel }}(122-5=117)$ adalah sebesar 1,980dan nilai signifikan 0,789 di atas signifikan 0,05 sehingga kesimpulannya adalah $\mathrm{t}_{\text {hitung }}<\mathrm{t}_{\text {tabel }}$ yaitu $\quad 0,269<1,980 \quad$ maka keputusannya adalah Ho diterima dan $\mathrm{H}_{\mathrm{a}}$ ditolak, artinya variabel Current Ratio, Perputaran Persediaan, Debt To Asset Ratio, Growth Dan Sizetidak berpengaruh Terhadap Profitabilitas Perusahaan Retail Sektor Trade, Investment Dan Service Yang Terdaftar Di Bursa Efek Indonesia Tahun 2016-2019.

5. Size mempunyai nilai thitung adalah sebesar 0,215 dengan nilai signifikan $\quad 0,830 \quad$ sedangkan $\mathrm{t}_{\text {tabel }}(122-5=117)$ adalah sebesar 1,980dan nilai signifikan $0,830 \mathrm{di}$ atas signifikan 0,05 sehingga kesimpulannya adalah $\mathrm{t}_{\text {hitung }}<\mathrm{t}_{\text {tabel }}$ yaitu $\quad 0,215<1,980 \quad$ maka keputusannya adalah Ho diterima dan $\mathrm{H}_{\mathrm{a}}$ ditolak, artinya variabel Sizetidak berpengaruh Terhadap Profitabilitas Perusahaan Retail Sektor Trade, Investment Dan
Service Yang Terdaftar Di Bursa Efek Indonesia Tahun 2016-2019.

\section{Pengaruh Current Ratio terhadap Profitabilitas}

Hasil penelitian diatas menunjukan bahwa Current Ratio tidak berpengaruh Terhadap Profitabilitas Perusahaan Retail Sektor Trade, Investment Dan Service Yang Terdaftar Di Bursa Efek Indonesia Tahun 2016-2019. Hasil penelitian ini tidak sejalan dengan Alpi (2018), menyatakan aktiva lancar adalah uang kas ataupun aktiva lainnya dapat diharapkan untuk dicairkan atau ditukarkan dengan uang tunai, dijual dalam periode berikutnya (satu tahun). Aktiva lancar tinggi akan mempengaruhi laba dimana perusahaan harus menyediakan persediaan yang cukup tinggi maka dapat menghasilkan penjualan tinggi dan meningkatkan laba perusahaan

\section{Pengaruh Perputaran Persediaan terhadap Profitabilitas}

Hasil yang didapat dari penelitian diatas menunjukan bahwa Perputaran Persediaan tidak berpengaruh Terhadap Profitabilitas Perusahaan Retail Sektor Trade, Investment Dan Service Yang Terdaftar Di Bursa Efek Indonesia Tahun 2016-2019. Hasil penelitian ini tidak sejalan dengan Widiasmoro (2017), menyatakan,semakin tinggi tingkat perputaran persediaan akan memperkecil resiko terhadap kerugianyang disebabkan karena penurunan harga atau karena perubahan selera konsumen, disamping itu akan menghemat ongkos penyimpanan dan pemeliharaan terhadap persediaan tersebut. 


\section{Pengaruh Debt To Asset Ratio terhadap Profitabilitas}

Berdasarkan penelitian diatas dapat diambil kesimpulan bahwa Debt To Asset Ratio tidak berpengaruh Terhadap Profitabilitas Perusahaan Retail Sektor Trade, Investment Dan Service Yang Terdaftar Di Bursa Efek Indonesia Tahun 2016-2019. Hasil yang berlawanan dengan Alpi (2018) Utang yang besar akan berdampak pada resiko keuangan yang harus ditanggung perusahaan atau terbebani dengan pembayaran bunga dalam jumlah yang besar.Namun apabila dana hasil pinjaman tersebut digunakan secara efisien dan efektif maka hal ini akan memberikan peluang yang besar bagi perusahaan dalam meningkatkan keuntungan.

\section{Pengaruh Growth terhadap Profitabilitas}

Berdasarkan penelitian diatas dapat diambil kesimpulan bahwa Growth tidak berpengaruh Terhadap Profitabilitas Perusahaan Retail Sektor Trade, Investment Dan Service Yang Terdaftar Di Bursa Efek Indonesia Tahun 2016-2019. Hasil penelitian ini tidak sejalan dengan Miswanto et al., (2017) mengatakan bahwa perusahaan yang meningkatkan pertumbuhan penjualan dengan menggunakan asset secara efisien dan mengarah pada penggunaan sumber daya yang optimal menunjukkan perusahaan tersebut dapat mempertahankan posisi ekonomi dan kelangsungan hidupnya memberikan dampak positif terhadap ROA. Ketika jumlah barang yang dijual semakin besar, maka biaya rata-rata persatuan produk akan semakin kecil sehingga ROA yang dihasilkan suatu perusahaan akan meningkat.

\section{Pengaruh Size terhadap Profitabilitas}

Berdasarkan penelitian diatas dapat diambil kesimpulan bahwa Size tidak berpengaruh Terhadap Profitabilitas Perusahaan Retail Sektor Trade, Investment Dan Service Yang Terdaftar Di Bursa Efek Indonesia Tahun 2016-2019. Hasil penelitian ini tidak sejalan dengan Wikardi \& Wiyani (2017) suatu perusahaan yang mempunyai ukuran yang cukup besar tentu dapat dikatakan memperoleh profit yang tingg karena mampu mengolah sumber daya yang ada di perusahaan tersebut.

\section{PENUTUP}

\section{Kesimpulan}

Dari hasil penelitian yang sudah dilakukan diatas maka dapat ditarik kesimpulan sebagai berikut :

1. Current Ratio tidak berpengaruh Terhadap Profitabilitas Perusahaan Retail Sektor Trade, Investment Dan Service Yang Terdaftar Di Bursa Efek Indonesia Tahun 2016-2019.

2. Perputaran Persediaan tidak berpengaruh Terhadap Profitabilitas Perusahaan Retail Sektor Trade, Investment Dan Service Yang Terdaftar Di Bursa Efek Indonesia Tahun 2016-2019.

3. Debt To Asset Ratio tidak berpengaruh Terhadap Profitabilitas Perusahaan Retail Sektor Trade, Investment Dan Service Yang Terdaftar Di Bursa Efek Indonesia Tahun 2016-2019.

4. Growth tidak berpengaruh Terhadap Profitabilitas Perusahaan Retail Sektor Trade, Investment Dan Service Yang Terdaftar Di Bursa Efek Indonesia Tahun 2016-2019.

5. Size tidak berpengaruh Terhadap Profitabilitas Perusahaan Retail 
Sektor Trade, Investment Dan Service Yang Terdaftar Di Bursa Efek Indonesia Tahun 2016-2019

6. Current Ratio, Perputaran Persediaan, Debt To Asset Ratio, Growth Dan Size tidak berpengaruh Terhadap Profitabilitas Perusahaan Retail Sektor Trade, Investment Dan Service Yang Terdaftar Di Bursa Efek Indonesia Tahun 2016-2019.

\section{Saran}

Berdasarkan penelitian dan pembahasan diatas, ada beberapa saran yang dapat disampaikan yaitu sebagai berikut :

1. Bagi Investor, hasil penelitian ini dapat menjadi bahan pertimbangan dimana Profitabilitas memiliki pengaruh besar terhadap Current Ratio, Perputaran Persediaan, Debt To Asset Ratio, Growth Dan Size sehingga investor dapat mempertimbangkan terlebih dahulu sebelum melakukan investasi.

2. Bagi peneliti selanjutnya, sebaiknya mengganti perusahaan sektor lain, menambah variabel independen lain yang mempengaruhi Profitabilitas.

3. Bagi Universitas Prima Indonesia, sebaiknya hasil penelitian ini dapat menambah karya ilmiah yang berada di perpustakaan berkaitan dengan faktor-faktor yang mempengaruhi Profitabilitas.

\section{DAFTAR PUSTAKA}

Alpi, M. F. (2018). Pengaruh Debt To Equity Ratio, Inventory Turn Over, Dan Current Ratio Terhadap Return On Equity Pada Perusahaan Sektor Farmasi yang Terdaftar di Bursa Efek Indonesia. The National Conference on Management and Business (NCMAB) 2018.
Lestiowati, R., \& Emita, I. (2018). Analisis Perputaran Persediaan dan Perputaran Piutang Terhadap Profitabilitas. AktivaJurnal Penelitian Ekonomi dan Bisnis, 2(1), 10-10.

Luckyta, A. C., Kartika, L., \& Rahmawati, S. (2020). Evaluasi Kinerja Organisasi Menggunakan Balanced Scorecard. INVEST: Jurnal Inovasi Bisnis dan Akuntansi, 1(1), 38-44.

Miswanto, M., Abdullah, Y. R., \& Suparti, S. (2017). Pengaruh Efisiensi Modal Kerja, Pertumbuhan Penjualan dan Ukuran Perusahaan Terhadap Profitabilitas Perusahaan. Jurnal Bisnis dan Ekonomi, 24(2).

Tannia, Y. (2020). Analisis Pengaruh Debt to Equity Ratio, Debt to Asset Ratio, Price Earning Ratio dan Price to Book Value Terhadap Harga Saham Pada Perusahaan Sektor Pertanian. INVEST: Jurnal Inovasi Bisnis dan Akuntansi, 1(1), 13-26.

Wikardi, L. D., \& Wiyani, N. T. (2017). Pengaruh Debt to Equity Ratio, Firm Size, Inventory Turnover, Assets Turnover dan Pertumbuhan Penjualan Terhadap Profitabilitas (Studi Kasus Pada Industri Makanan dan Minuman yang Terdaftar di BEI Periode 2011-2015). Jurnal Online Insan Akuntan, 2(1), 99118.

Widiasmoro, R. (2018). Pengaruh Perputaran Kas, Perputaran Piutang, dan Perputaran Persediaan Terhadap Profitabilitas/Roa Pada Perusahaan Manufaktur Indonesia Tahun 20112014. Smooting, 15(3). 